
United Kingdom Since the Nineteenth Century

\title{
Doomwatch and the Environment in Britain, 1970-
}

\section{C.1974}

Doomwatch et l'environnement en Grande-Bretagne, 1970-74

\section{Mark Wilson}

\section{CpenEdition}

\section{Journals}

Electronic version

URL: http://journals.openedition.org/rfcb/2621

DOI: $10.4000 /$ rfcb. 2621

ISSN: 2429-4373

Publisher

CRECIB - Centre de recherche et d'études en civilisation britannique

Electronic reference

Mark Wilson, « Doomwatch and the Environment in Britain, 1970-c. 1974 », Revue Française de Civilisation Britannique [Online], XXIII-3 | 2018, Online since 07 December 2018, connection on 01 May 2019. URL : http://journals.openedition.org/rfcb/2621 ; DOI : 10.4000/rfcb.2621

This text was automatically generated on 1 May 2019.

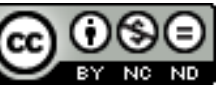

Revue française de civilisation britannique est mis à disposition selon les termes de la licence Creative Commons Attribution - Pas d'Utilisation Commerciale - Pas de Modification 4.0 International. 


\title{
Doomwatch and the Environment in Britain, 1970-c.1974
}

\author{
Doomwatch et l'environnement en Grande-Bretagne, 1970-74
}

Mark Wilson

\section{Introduction}

1 In January 2018, British Prime Minister Theresa May introduced a 25-year environmental plan for the country. Included in it was a mention of the possible creation of a worldleading, independent body "championing and upholding environmental standards." ${ }^{1}$ February 1970 saw a similar organisation appear for the first time on television. The BBC launched a new science fiction television series about an independent body dealing with environmental, technological and scientific issues. The organisation (and the eponymous series it featured in), known as Doomwatch, will be analysed below, by placing it within the wider context of early 1970s Britain, a period of burgeoning environmental discourse within British society. Reflecting the public's mood at the beginning of this decade, for instance, on 1 February 1970, The Guardian newspaper proudly exclaimed that "We are all conservationists now." ${ }^{2}$ The newspaper noted that environmental problems of the previous few years, from air pollution in the 1950s, to the sinking of the oil tanker Torrey Canyon in 1967, had made the public more aware of environmental issues in society.

2 Showing the significance of considering the media in the narrative of the "greening of Britain," along with more traditional sources, this article argues that Doomwatch should be considered as part of any study about the rise of environmental awareness. Beginning with an assessment of the political and environmental landscape of early 1970s Britain, the article then describes how Doomwatch both fit into and developed this landscape, by analysing the series using the ideas of cultural theorist Stuart Hall. Finally, it questions and assesses the impact Doomwatch had on its audiences, and reflects the importance that the media played in the growth of environmental awareness. In particular, it asks why Doomwatch was so popular with the public at the time: from the BBC Audience Research Reports, it is clear how viewers felt about the programme and its themes. Britain in 1970 
saw a flurry of environmental-themed issues. The Department of the Environment, and The Ecologist journal were both established in that year, with the pressure group Friends of the Earth appearing a year later. The first United Nations Environment Conference was held in Stockholm in 1972, and the forerunner to the modern day Green Party was established early in 1973. ${ }^{3}$ Words such as "ecology" and "pollution" became commonplace, and people were acutely aware that if something went wrong in one place, it may also go wrong somewhere else. ${ }^{4}$ From the analysis of Doomwatch and its impact on the British public, the article contemplates the need to consider actors involved in the development of environmentalism that are often ignored, such as television programmes. Television provides viewers with an experience quite different from novels and films audiences know that the end of the narrative has been written as soon as they start to read a novel or watch a film - while "in television serials ... the future appears to be as unwritten as our own." Doomwatch, often described as "science fact-fiction," allowed contemporary problems to enter people's homes, and questioned scientific wisdom each week. It ensured issues became and remained prominent. ${ }^{6}$ Doomwatch has been underexplored in many environmental narratives of the period, perhaps because it has fallen into relative obscurity in recent years (for instance, the DVD of the series was only released in 2016. The DVD was also incomplete, the BBC having lost some of the episodes). Despite this, the Audience Research Reports reveal what the series focused on and how successful the show was at communicating its message. The Research Reports, which were reports and questionnaires about BBC programmes completed by viewers, show what audiences felt. Doomwatch fueled the rise of environmentalism by bringing disparate, and under-discussed, or unknown environmental issues into the public sphere and allowed discussion and debate on these issues across society.

Cultural theorist Stuart Hall argued that when interpreting a television programme, the whole programme should be viewed as one, rather than viewing it as a set of different scenes and episodes. The best way to understand the impact a television programme has had is by finding out how the audience felt watching it. ${ }^{7}$ Thus, through these Research Reports, a growing environmental awareness can be observed as the audience connected what they saw on screen to real-life issues. One Report described how the series always left audiences with a case of dread, that what they saw in the series could happen in reality. ${ }^{8}$ One of the main actors in the first season of Doomwatch, Robert Powell, said in a 2006 documentary about the series, "at least half the stories that we were doing... came true." At the time, the series felt fresh and real. Indeed, the series creators would search through recent news articles and journals, finding plenty of possible topics. Furthermore, they would give the episode writers a basic outline of the story, which would then be developed into a fifty-minute adventure. ${ }^{10}$ Although Doomwatch dealt with issues that were in vogue or coming into vogue at the time, it also reflected issues which had emerged in Britain since the end of the Second World War, namely, technological development and the contentious role of technology and science in society.

\section{Post-War Britain \& Technological Development}

Rising wages and new technology, often by-products of technologies developed during the war, saw Britain becoming a consumer society as the 1950 s progressed. ${ }^{11}$ At the beginning of the decade, according to Jack Williams, less than a tenth of all households had a television set; ten years later, in 1961, this figure had risen to three quarters of all 
households. Similarly, in 1950, only about 350,000 combined radio and television licences were sold (compared with over 11 million radio only licences); ten years later the combined licences had risen to over 10 million, more than double the radio-only licences. ${ }^{12}$ Nicholas Abercrombie notes how 1961 also saw men in full-time employment spend an average of two hours per day watching television, compared with less than half that listening to the radio, reading a book or newspaper. Women in full-time employment watched television for an average of about one and half hours each day, compared again to less than half that listening to the radio or reading. ${ }^{13}$ Thus, from the 1960 s onwards, people in Britain spent more of their non-work waking hours watching television than on any other activity. Further evidence of the growth of television, Williams states, comes from television's share of all advertising expenditure, which rose from 6 per cent in 1957 to 22 per cent three years later in 1960 . Also, by that year, nearly all newspapers included television listings. ${ }^{14}$ The television age had begun. Environmentally-themed television programmes brought the natural environment into people's homes, leading to a growing concern about the impact of humans on the environment. Technology seemed to hold the key to advances within society and to peace and prosperity. The advent of this technological revolution promised to provide affordable and unlimited energy to create a more equitable society. However, some did not believe this; they were increasingly sceptical about the dominance of a society controlled by technology, and several events in the 1950s and 1960s only reinforced this belief. ${ }^{15}$ For Doomwatch to succeed, it needed to be as realistic as possible, not just regarding the science, but in its portrayal of scientists themselves. The idea was that this would be a science fiction that could conceivably take place today or tomorrow. The programme's creators "did not want any Doctor Who style mad scientists threatening to destroy the world - there were enough sane ones doing that already." 16

5 Doomwatch was conceived at the end of the 1960s. ${ }^{17}$ The environmental - and technological - issues of the day were adapted and featured in various guises throughout the series. From the thick blanket of fog, which covered much of London for several days in December 1952, Britain's first post-war environmental disaster, through to the publication of Rachel Carson's seminal work Silent Spring, to the sinking of the oil tanker Torrey Canyon and the Thalidomide disaster, by the end of the 1960s, mistrust of science and technology had begun to be realised in Britain. The death of some farm animals in Kent in 1963 brought home the realisation that scientific progress could have some very real and very negative consequences..$^{18}$ Then, in October 1966, a slag heap in the Welsh town of Aberfan, near Merthyr Tydfil, collapsed, killing 143 people, including over 100 children. The heap covered a farmhouse, twenty houses and two schools. ${ }^{19}$

6 The Times described the disaster as an environmental one - that of dumping waste which was a feature of "the industrial rape of the environment" with the heaps of the waste of industrial development, "towering over villages and farmsteads, dehumanising the environment and even threatening human life ... symbols of the false values of an acquisitive culture." 20 The threat to human life by science and technology was a recurring theme throughout the whole of Doomwatch. More often than not, a good idea on paper, such as Variant 14, the plastic-eating virus which appears in the first episode of the series, ends up being disastrous, because of human oversight and accidents.

7 Following these disasters, therefore, by the end of the 1960s, there was a view by some, such as some members of the Conservation Society (established in Britain in 1966), that technological dependence was a bad thing and wanted something done about it. ${ }^{21} \mathrm{An}$ 
understanding developed that the environment was being destroyed by humans, and this destruction was increasing in frequency and scale. ${ }^{22}$ Doomwatch fed into this understanding and concern about the dangers of unregulated scientific and technological growth, and about how some companies would put commercial interests ahead of public safety. This was seen in the series one episode "The Devil's Sweets" (broadcast in March 1970). ${ }^{23}$ The story involved "behavioural drugs being developed by a cash-strapped university department and how a former student, who was now an unscrupulous advertising man, used a sample for his own ends." ${ }^{24}$ Cigarette sales, the audience was told, had increased by a massive amount in certain areas of London, with one brand (called Checkerboard) selling out in many stores. Across the road from one such store was a chocolate factory giving out free samples. Both the cigarettes and the chocolate factory were represented by the same advertising agency, the owner of which was still linked to his university, which itself was experimenting with a phototropine drug. In return for money given to the university, the professor leading the experiment allowed this ex-student to take the drug away, and put it in the chocolate. Anyone who ate the chocolate would later smoke Checkerboard cigarettes, the checkerboard packaging subliminally encouraging people to smoke. ${ }^{25}$ In the episode "The Red Sky," about noise pollution caused by a new jet aircraft, one character suggested that the aircraft manufactures could put up sound barriers to muffle some of the noise. ${ }^{26}$ The response was that it would reduce the company's profit, the implication being that money was more important than people's health.

In November 1970, the new Conservative government established the Department of the Environment, with Peter Walker as the first Secretary of State for the Environment. By this time, there was enough concern about environmental problems, particularly pollution, to make establishing this new department logical. ${ }^{27}$ The Department, " $a$ very novel creation," now had power to deal with a host of environmental problems, and despite some failings, it did give pressure groups a way to access central government. ${ }^{28}$ Walker's position as Environment Secretary gave him powers which were not available to his counterparts in Europe. ${ }^{29}$ The Department's aims included the renewal, improvement and protection of the environment. Its first priority was to ensure the environment could be enjoyed by the population as a whole. Another aim was to conserve rural and urban areas, ensuring that things beautiful and good survived across the country. ${ }^{30}$ The two creators of Doomwatch, Kit Pedler and Gerry Davis, were even invited to the Department to meet Walker, as well as the Shadow Secretary of State for the Environment, to discuss the creation of a real-life department whose remit would be similar to that of Doomwatch on television. ${ }^{31}$ Although this came to nothing, it shows the level of influence and the effect the programme had on society. In the run-up to the first United Nations Environment Conference, in Stockholm, in 1972, there was also some discussion of the possibility of creating a real-life Doomwatch-style department. "This would be a global agency watching over the state of the environment." Then, in the formal proposal before the conference, there was "something called an 'Earth-watch Agency' which is really ... the same thing. It is an agency to check continually on the state of the environment." ${ }^{32}$ By 1970 many people showed "an increasing awareness of the need to prevent further erosion of the natural environment and to take positive steps to enhance the quality of life." ${ }^{33}$

In light of the concerns about environmental destruction in the 1950s and 1960s, Gerry Davis and Kit Pedler created a new environmental television series which would not only be popular but arguably also do its bit to ensure environmental issues were considered nationally, and globally (such as the suggestion of the "Earth-watch Agency" above). 


\section{Doomwatch} Everything made of plastic, including all the flight instruments, starts to melt. The plane crashes, with a loss of all on-board. Thus began "The Plastic Eaters," the first episode of Doomwatch. ${ }^{34}$ The series revolved around a fictional department tasked with protecting the world from unregulated scientific research. Although it also dealt with science and technology, the series began with the theme of pollution, specifically in relation to litter and rubbish. The department was run by fictional scientist Dr Simon Quist, previously a Manhattan Project scientist during the Second World War. Quist described Doomwatch as such:

Our proper name is 'Department of Measurement of Scientific Work.' But 'Doomwatch' is easier and perhaps it's more correct, too. ... Our work's very important ... Science has given the world many good things - but science can also be dangerous. Sometimes scientists make mistakes; they can be careless. So the Government have started 'Doomwatch'. We're all scientists too, and we watch all the scientific work in Britain. If we're sure that the work is safe, we do nothing. But sometimes we find work that may be dangerous. And then we have to stop it. ${ }^{35}$

Doomwatch episodes often began with a problem, such as the plastic on the aeroplane melting, in "The Plastic Eaters." The Doomwatch team would then receive news about the problem, and set to work investigating. Usually the investigation would be hampered by bureaucracy, the government or industry, who did not want the public to find out what had been happening. By the end of the episode, the team would usually (though not always) have solved the problem.

Television programmes, Stuart Hall argued, can be interpreted in different ways. Scenes in television programmes do not signify anything on their own, he states, as it is only when they are combined with other scenes that the message is broadcast. ${ }^{36}$ In other words, context is important..$^{37}$ Hall's theory, a process of encoding/decoding, describes the process programmes undergo, from inception to transmission. Producers develop an idea and create a programme, encoding it with their message. This is then aired and decoded by the audience, though not always in the same way as the producers originally intended. ${ }^{38}$ Often, images used in programmes - for example the photograph of a cow are interpreted as they should be, by the audience, because they "look like objects in the real world" and they "reproduced the conditions of perception in the receiver [viewer]." ${ }^{39}$ The Audience Research Reports are useful ways of analysing the series as they provide the opinions of viewers and how the audience felt through watching the programme. Whilst they do not reflect the views of all viewers, they nevertheless provide insights into how the series was perceived by the general public.

Watched by an estimated 16.2 per cent of the population (as noted in the Audience Research Report), "The Plastic Easters," aired on 9 February, 1970. Featuring a virus that could eat through plastic (Variant 14, created to get rid of rubbish), the Research Report for this episode described the series as having "a very promising start" and was "a change from the usual type of science fiction" with the story being "believable and gripping." ${ }^{40}$ The episode was also described by some as being "not so very improbable these days" and it was believed that the story was "frighteningly possible." ${ }^{41}$ Of particular note is the fact the virus escaped from the laboratory by lack of human oversight, rather than being deliberately

Revue Française de Civilisation Britannique, XXIII-3 | 2018 
released, again increasing the plausibility and tension in the viewer. Over three seasons and 38 episodes, the creators, Dr Kit Pedler, an "all-round scientist," and Doctor Who story editor Gerry Davis, decided which stories to be used each week. ${ }^{42}$ Meeting Davis at the BBC (Pedler had been Doctor Who's unofficial scientific advisor since 1966, and both men were the masterminds behind the Cybermen in that series), they discussed environmental problems and how science was no longer serving humanity but instead corporate vested interests. They recognised the scientific honeymoon was over. It was time for a different take, a more realistic approach to science fiction. ${ }^{43}$ Doomwatch reflected both men's shared concern about the role of scientific investigation on society. In their blurb to writers of the series, Pedler and Davis described the theme of the programme as adventures in the scientific field where the human condition is forgotten, essentially, " science fact-fiction." ${ }^{44}$

David Morley supports the usefulness of Hall's model for assessing television programmes and particularly in using the Research Reports to analyse viewer opinions. ${ }^{45}$ The best way to understand how viewers respond to television programmes, he argues, is having them watch programmes and then having them write about how they felt and what they considered the programme to be about. This works better than having an analyst simply imagining "the possible implications of how other people might watch television." ${ }^{46}$ Context is always important in interpreting television programmes, something Hall and Morley both stress as central to their interpretations ${ }^{47}$ Hall's and Morley's ideas can be applied directly to the audience's reaction. Rather than projecting a particular image which viewers would recognise, the producers of the series portrayed a set of events and disasters which reflected the real world. This was not lost on the audience. Some Research Reports claimed that episodes of the series were too much like real life. Although Doomwatch was science fiction, it mirrored real life so convincingly that its stories often had more than an element of truth to them. It can be argued that the audience went further than the producers intended. This is particularly evident in the responses to an episode in the second series, entitled "The Human Time Bomb," which aired on 22 February 1971. Dealing with the very topical issue at the time of population growth and problems associated with it, the episode discussed possible future accommodation styles, such as tower blocks. It was described in the Audience Research Reports as being believable:

[W] all know this is fiction but unfortunately yesterday's fiction is often today's fact and, certainly, this study of the tensions that could develop in those living in towering blocks of flats seems uncomfortably near reality, in several opinions. It was a programme that highlighted one of today's social problems, and proved both entertaining and thought-provoking ... Doomwatch always leaves me with something to think about such as 'can that really happen?' In most cases the answer is 'Yes' so if there isn't a real Doomwatch, there ought to be one. ${ }^{48}$

Other stories were described as being similarly realistic. The final episode of the first series, entitled "Survival Code," aired on 11 May 1970 with 22.7 per cent of the United Kingdom's population watching (according to the Research Report). This story involved a military plane crashing, carrying nuclear weapons on board, and a member of the Doomwatch team having to defuse a bomb. It was again described as believable, displaying:

a strong sense of realism, not only in the way the various characters reacted to danger and the understandable antagonism between the military and Doomwatch personnel, but in its highlighting of the very real hazards to which members of the public may be subjected without their knowledge..$^{49}$ 
The episode was even criticised for being a little too believable, with one reviewer stating that they were aware of a similar incident which had already occurred, with another claiming Doomwatch was more like "fact than fiction." It was also noted that, as well as providing an entertaining and informative story, the series was worth watching as a " clear and realistic look at a variety of subjects in the not-too-distant future - and indeed the present, some added, the immunity of some rats to pesticides, and the experimentation with live foetuses having already been reported." ${ }^{50}$

\section{Doomwatch's popularity}

As the series aired its first few episodes, the media noticed that an uncanny coincidence was taking place. People realised that these were not just fictional stories, but had a very real base from which the stories developed. Michael Mills, Head of Light Entertainment at the $\mathrm{BBC}$, felt this made the series far more frightening than Doctor Who. It also appealed to those sections of the population who were more sceptical or distrustful of the government. "As the series continued ... more of the episodes rang alarm bells of recognition with the viewer... There was a huge public outcry over American plans to dump chemical weapons 280 miles off the Florida coastline, highly intelligent rats were discovered in America, and poison resistant ones were found in Wales", all themes of Doomwatch stories..$^{51}$ In Parliament during a discussion on noise pollution, the episode "The Red Sky," (which was about a new jet aircraft and the noise it made), one MP directly quoted from this episode in their contribution to the debate..$^{52}$

18 The popularity of Doomwatch did not emerge only from the programme's scientific plausibility but also its political plausibility, with The New York Times describing it as " exceptionally sophisticated for a mass entertainment drama" on a State-owned television network..$^{53}$ The series, which ran for over three seasons, achieved consistently achieved high viewing figures and its name reflected a sense of concern over the environment. ${ }^{54}$ After the first programme aired, some newspapers began running "Doomwatch" columns, relating to environmental themes which appeared during the series..$^{55}$ In June 1970, the newspaper Daily Mirror even created their own Doomwatch team to investigate environmental problems, and report on them, inviting readers to get in touch with the team about their concerns. "Many people in Britain fear the effects of scientific progress," the team's advertisement in the newspaper ran. "Technology is all very well, but what are the scientists doing to YOUR lives?" 56 The team included Pedler, who would be involved with trying to find a solution to the problem. In the following years, it took a crusading stand on environmental problems. Other newspapers soon rallied to the cause, as they realised that environmental issues were no longer niche issues, but widespread across society..$^{57}$

The word "Doomwatch," even entered the Oxford English Dictionary in $1970 .{ }^{58}$ Doomwatch became a catch-all term to describe "sinister experiments and technological hazards to human life." ${ }^{59}$ When used as an adjective, however, there was no explanation as to what it meant (often articles described "Doomwatch-style events" or advocated the establishment of a " Doomwatch-style department"). ${ }^{60}$ The fact that newspapers did not explain what they meant by "Doomwatch" shows how significant the television programme was. The series had become so embedded in the British psyche that no further explanation was needed. In a Times newspaper article from 1972, for instance, the term "Doomwatch dial" was used in reference to school children studying lichen as an indication of pollution levels. ${ }^{61}$ 
Likewise, a search of British Hansard with the word "Doomwatch" shows its being used only from 1970, and only in connection with anything negative to do with the environment. ${ }^{62}$ When the Environment Secretary was asked in 1972 what he thought of the "Doomwatch" approach to science, he expressed his support for the "Doomwatch" lobby, stating that if there was a similar strong lobby in the United States, they would not be in the situation they were in, with lakes dying and pollution running rampant. If there had been "a few good doomwatchers" 30 years previously, he declared, current environmental problems in Britain may not exist. ${ }^{63}$

The Doomwatch team were a small team, and armed with "little more than sound reasoning," but often, this was enough. ${ }^{64}$ The series brought science and technology into the homes of the public, introducing them to many important issues of the day. The writers were never short of ideas, either. All they had to do was open a newspaper. ${ }^{65}$ The factual elements of the series ensured that thought-provoking stories entered people's consciousness; this is revealed in the Audience Research Reports, which described the programme's realism and made comparisons to real-life events. The series was special, one viewer commented, because episodes "touch on things the layman never gives a second thought to," and "make people realise how progress can get out of hand," with episodes leaving "food for thought" and viewers with a feeling that "this could come true." 66

Invariably, fiction would also mirror fact. For instance, "The Human Time Bomb," aired the same year as the creation of a Population Panel by the government to "assess the available evidence about the significance of population growth for both public affairs and private life in this country." ${ }^{67}$ As a comment on air pollution, which has reverberations today in cities like London and Paris, the production team even produced a story about the dangers of leaded petrol (series three episode "Waiting for a Knighthood"). Following the airing of this story, director Pennant Roberts described how perhaps the programme did its bit in introducing unleaded petrol, not only in Britain, but also around the world, further highlighting the immediacy of the series and its position as an instigator of profound changes in social attitudes. ${ }^{68}$

\section{Conclusion}

Although the special effects today now look very dated, the stories have stood the test of time remarkably well. Indeed, when some proposed renewing the series, in the early 2000s, all the ideas the writers came up with had already been shown in the original series. ${ }^{69}$ Yet the series remains significant, not only because it was so popular with the British public (regularly getting over 10 million viewers), but also because it was not like any other science fiction television programme at the time. It is this realism that makes the series so important and unique to discuss. As observed above through discussion of the Research Reports relating to specific episodes, and the wider "Doomwatch effect," the series was instrumental in raising awareness of scientific, technological and environmental problems which society faced. It shows how these issues were viewed in society at the time and is evidence of a growing environmental awareness in 1970s Britain. The responses to the series were not fantastical; instead viewers often recognised the realism of the series. Cutting-edge in every sense of the word, Doomwatch finished airing in 1972, after three series. Although the series had been important in introducing new ideas into people's homes, eventually production problems forced the end to the series. Pedler and Davis found they had less authority over the types of stories which 
were developed and there was a feeling that some of the later stories were not real " Doomwatch" stories. ${ }^{70}$

Environmental awareness, however, continued apace to grow in the later years of the decade, with the launch of Greenpeace in Britain in 1977. Yet, it was in the first few years of the 1970s that concerns became more entrenched in British society, and in the public's thinking about issues. Whilst the Doomwatch department was considered, in the series, to be a political creation to appease the so-called green movement, it actually turned out to be quite strong, with Quist and his team continuing their work in the face of political and industry opposition. And, in the real world, although there was no real life Doomwatch department, pressure groups emerged at the beginning of the 1970s, such as Friends of the Earth, who kept the environment on the political agenda. In Newcastle upon Tyne, a local pressure group called Tyneside Environmental Concern (or TEC, for short), was created in 1970, following a talk given by Kit Pedler in the city. ${ }^{71}$ This environmental concern in British society can be seen in the early years of the 1970s through the founding of the Department of the Environment, and, on television, through Doomwatch. The series was "a 'green' programme years ahead of its time, capturing the public imagination."72 Its appeal stemmed from the themes of the episodes which were not set on an alien planet with make-believe stories; instead, the series dealt with real-life issues in a very real setting. Through "science fact-fiction," the series allowed important environmental messages to enter the homes - and lives - of the general public. Its messages were not lost on the audience, many of whom saw comparisons between the stories in the series, and real life problems, such as the concern about population growth and use of leaded petrol. In later episodes, the series also dealt with contemporary social issues, such as drugs and sex. Never away from controversy, Doomwatch helped cement and establish environment problems within the British public's psyche.

There has been relatively little scholarship on Doomwatch. The detailed fan website no longer exists, and it was not until 2016 that the BBC released a DVD of the surviving episodes. Some may be lost forever. Michael Seely has written a biography of Kit Pedler, however, which has been made use of here. It is true that the series cannot be looked at in isolation - as Hall says, context is important - and Doomwatch should be considered within the wider context of the late 1960s and early 1970s, a period when technology and science was greatly advancing, and environmental awareness was developing. Whilst Doomwatch cannot be described as the sole reason that environmental awareness grew in the 1970s, it certainly contributed, and reflected real world problems of pollution and ecological degradation. The Audience Research Reports, reflecting the views of members of the audience, show that people were concerned about the environment, and identified with the programme, and Doomwatch was part of a developing environmental discourse.

At the time it regularly drew an audience of 10 million and fed into a developing ecological consciousness which still exists today. When looking at environmental awareness, television should not be ignored in analysis, and as the Research Reports show, not only was there a correlation between what happened in the series and what was happening in real life, but they also reveal how people connected what they saw in the series to real life. Ultimately, Doomwatch fed into a growing environmental awareness which was developing in British society at the time, but also helped to strengthen this awareness - without this series, the public would have been less informed, and less aware of certain environmental issues. 
Mark Wilson has a PhD in History, and works on the growth of environmental awareness in Britain after the Second World War, 1945-c.1975. He writes about the impact television programmes have had on raising awareness of the environment, and has broad interests in environmental, animal and cultural histories. He currently works as an English teacher in Asia.

\section{NOTES}

1. HM Government, "A Green Future: Our 25 Year Plan to Improve the Environment", p. 139 https://www.gov.uk/government/uploads/system/uploads/attachment_data/file/673203/25year-environment-plan.pdf - accessed electronically 21 January 2017.

2. Jeremy Swift, "How Conservation Came to Town", The Guardian, 1 February 1970, p. 8.

3. Mike Robinson, The Greening of British Party Politics (Manchester, Manchester University Press, 1992); Brian Doherty, Ideas and Actions in the Green Movement (London, Routledge, 2002).

4. Adam Fergusson, "Pollution: waking up to the mess", The Times, 31 December 1969, p. 5; Dennis Johnson, "Saving the green", The Guardian, 19 October 1970, p. 11.

5. John Fiske, 'Moments of television: Neither the text nor the audience', in Ellen Seiter, Hans Borchers, Gabriele Kreutzner \& Eva-Maria Warth (eds.), Remote Control: Television Audiences and Cultural Power (London, Routledge, 2013), p. 67.

6. Commissioning Brief from G. Davis for story "Your Body Will Never Forgive" (Second Series, episode 27), T48/333/1 - Malcolm Hulke (Drama Writer's File), BBC Written Archives Centre (hereafter WAC), Reading.

7. Stuart Hall, "Encoding and Decoding in the Television Discourse", Centre for Contemporary Cultural Studies - Media Series No. 7, September 1975, p. 5.

8. Doomwatch episode "The Human Time Bomb", originally aired 22 February 1971, directed by Joan-Kemp Welch, R9/7/109 - Audience Research Reports - Television - General Chronological January \& February 1971, WAC.

9. Robert Powell, The Cult of... Doomwatch, Documentary, directed by Tony Fullwell (2006: BBC).

10. Michael Seely, The Quest for Pedler: The Life and Ideas of Dr Kit Pedler (Surrey, Miwk Publishing, 2014), p. 145.

11. See Matthew Hilton, Consumerism in $20^{\text {th }}$ Century Britain (Cambridge, Cambridge University Press, 2003), pp. 3-4, 309. See also Meredith Veldman, Fantasy, the Bomb and the Greening of Britain: Romantic Protest, 1945-1980 (Cambridge, Cambridge University Press, 1994), pp. 4-5.

12. Jack Williams, Entertaining the Nation: A Social History of British Television (Stroud, Sutton Publishing Limited, 2004), p. 14.

13. Nicholas Abercrombie, Television and Society (Cambridge, Polity Press, 1997), p. 148. Adapted from Jonathan Gershuny \& Sally Jones, "The changing work/leisure balance in Britain: 1961-1984", in John Horne, David Jary \& Alan Tomlinson (eds.), Sport, Leisure and Social Relations (London, Routledge, 1987), p. 47.

14. Williams, Entertaining the Nation, pp. 95-96.

15. Veldman, Fantasy, the Bomb and the Greening of Britain, pp. 4-5.

16. Seely, The Quest for Pedler, p. 144.

17. Ibid., p. 147. 
18. See John Clark, "Pesticides, pollution and the UK's Silent Spring, 1963-64: Poison in the garden of England", Notes and Records of the Royal Society 71: 3, 2017, pp. 297-327.

19. Cledwyn Hughes, “Aberfan Disaster”, Hansard, HC Deb. vol 734 cc643-9 (24 October 1966).

20. Anon, "The Black Tragedy of Aberfan", The Times, Friday 4 August 1967, p. 9.

21. Appendix 9, "Why Britain Needs a Population Policy: Memorandum by the Conservation Society", Select Committee on Science and Technology, Session 1969-1970, p. 287.

22. Lord Henley described many different environment problems of the late 1960s and which would dominate the 1970s. See Lord Henley, "Development and Threats to Amenity", Hansard, HL Deb., vol. 299 cc. 821-904 (19 February 1969).

23. “The Devil's Sweets”, Doomwatch, directed by David Proudfoot (23 March 1970: BBC).

24. Seely, The Quest for Pedler, p. 148.

25. Ibid.

26. “The Red Sky", Doomwatch, directed by Jonathan Alwyn (6 April 1970: BBC).

27. Tony Aldous, Battle for the Environment (London, Fontana, 1972), p. 23.

28. John S. Dryzek, David Downes, Christian Hunold, David Schlosberg \& Hans-Kristian Hernes (eds.), Green States and Social Movements: Environmentalism in the United States, United Kingdom, Germany and Norway (Oxford, Oxford University Press, 2011), p. 44.

29. Aldous, Battle for the Environment, pp. 11-13, 16.

30. Ibid, pp. 27-28, 38-39.

31. Seely, The Quest for Pedler, p. 180.

32. "The Human Environment: Stockholm Conference", Hansard, HL Deb., vol. 330, cc.191-268 (20 April 1972).

33. J.M.C. James, "Man and nature in partnership", The Times, 16 June 1970, p. 11.

34. "The Plastic Eaters", Doomwatch, directed by Paul Ciapessoni (9 February 1970: BBC).

35. Doomwatch Manuscript, "Doomwatch: The World in Danger", based on the television programmes by Kit Pedler and Gerry Davies, edited by Gordon Walsh, R43/999/1, WAC. This is a manuscript of three Doomwatch stories, including "The Plastic Eaters", which were to be converted into book format for children to read. The quote by Quist appears on p. 6 of "The Plastic Eaters'. The book was to form part of the Longman Structural Readers series Stage 4 Non-Fiction, n.d., likely to be 1974/1975.

36. Hall, "Encoding and Decoding", p. 5.

37. Ellen Seiter, Television and New Media Audiences (Oxford, Oxford University Press, 1999), p. 15. David Morley also describes how important context is - see David Morley, "Changing paradigms in audience studies", in Ellen Seiter, Hans Borchers, Gabriele Kreutzner \& Eva-Maria Warth (eds.), Remote Control: Television, Audiences and Cultural Power (Oxford, Routledge, 2013), pp. 38--39.

38. Hall, "Encoding and Decoding", p. 4.

39. Ibid., p. 11.

40. Doomwatch episode "The Plastic Eaters", originally aired 9 February 1970, directed by Paul Ciapessoni, R9/7/103 - Audience Research Reports - Television - General Chronological January \& February 1970, WAC.

41. Ibid..

42. Pedler was described as such by Robert Llewellyn (narrator), The Cult of... Doomwatch, Documentary, directed by Tony Followell (BBC, 2006).

43. Tony Darbyshire, "Embryonic Nazis on Four Legs", in Doomwatch Fanzine: Issue 1 (n.d. likely to be 2010), p. 3 - https://www.scribd.com/document/65967232/Doomwatch-Fanzine-Issue-1\# accessed electronically 7 October 2017.

44. Seely, The Quest for Pedler, p. 145.

45. Morley, "Changing paradigms in audience studies", p. 18.

46. Ibid., p. 24.

47. Ibid., pp. 18, 38-39. 
48. Doomwatch episode "The Human Time Bomb", originally aired 22 February 1971, directed by Joan-Kemp Welch, R9/7/109 - Audience Research Reports - Television - General Chronological January \& February 1971, WAC.

49. Doomwatch episode "Survival Code", originally aired 11 May 1970, directed by Hugh David, R9/7/105 - Audience Research Reports - Television - General Chronological May \& June 1970, WAC.

50. Ibid.

51. Seely, The Quest for Pedler, p. 172.

52. Ibid., p. 173.

53. Alan Brien, "London: Of Man, Rats and the Absurd", The New York Times, 6 April 1970, p. 48.

54. BBC Accounts and Annual Report, 1969-1970, (Cmnd. 4520), p. 59.

55. See Arthur Smith, "Blueprint for Survival”, Daily Mirror, 14 January 1972, p. 4. Another section of the piece with a different headline - "Goldfish keep guard on 'drums of death"'. Both pieces are on a half-page feature surrounded by a black box with white writing which read "Doomwatch" ten times around the box - five at the top and five at the bottom.

56. Seely, The Quest for Pedler, p. 184.

57. Ibid..

58. Doomwatch episode "The Plastic Eaters", originally aired 9 February 1970, directed by Paul Ciapessoni, R9/7/103 - Audience Research Reports, WAC; See Oxford English Dictionary entry for "Doomwatch" - http://www.oed.com/view/Entry/56817?redirectedFrom=Doomwatch\#eid accessed electronically 3 March 2017.

59. Seely, The Quest for Pedler, p. 169.

60. Anon, "Children to survey pollution", The Times, Monday 19 June 1972, p. 14.

61. Ibid..

62. Search: Doomwatch - http://hansard.millbanksystems.com/search/doomwatch? decade=1970s\&page=1 - accessed electronically 3 May 2017. In a debate about population in 1972, one MP said to the Prime Minister that he should not be influenced by people who are described as “"doomwatchers"' - Sir Gilbert Longden, "Population", Hansard, HC Deb., vol. 846 cc.1515-6 (23 November 1972).

63. Interview between John Tusa and Peter Walker, 28 October 1971, in Schools Television: New Horizons - Science \& Survival (Industry and the Environment) T69/36/1, Programme 3, Spring Term (File 2), WAC - transmitted 25/26 January 1972.

64. Robert Llewellyn (narrator), The Cult of... Doomwatch, Documentary, directed by Tony Followell (BBC, 2006).

65. Ibid.

66. Doomwatch episode, "The Logicians", originally aired 15 March 1971, directed by David Proudfoot, R9/7/110 - Audience Research Reports - Television - General Chronological March \& April 1971, WAC.

67. Report of the Population Panel (London, HMSO: 1973, Cmnd. 5258), p. vii. See - https:// www.populationmatters.org/documents/population_panel.pdf - accessed electronically 3 May 2017.

68. Pennant Roberts, The Cult of ... Doomwatch.

69. Kim Newman, The Cult of... Doomwatch.

70. Seely, The Quest for Pedler, pp. 187-194.

71. K. A. Pollock, "Doomwatch", Muther Grumble 2, February 1972 - http:// www.muthergrumble.co.uk/issue02/mg0208.htm - accessed electronically 21 January 2018.

72. "Obituary: Simon Oates: Actor who starred as scientist Dr John Ridge in Doomwatch", The Independent, Sunday 21 June 2009 - http://www.independent.co.uk/news/obituaries/simonoates-actor-who-starred-as-the-scientist-dr-john-ridge-in-lsquodoomwatchrsquo-1712387.html accessed electronically 7 October 2017. 


\section{ABSTRACTS}

From the establishment of the Department of the Environment, in 1970, to the launch of the Green Party in 1973, the first few years of the 1970s saw environmental issues move to the centre of British society. This article discusses environmental awareness in this period, with specific reference to the $\mathrm{BBC}$ science fiction series Doomwatch. Placing this series within the wider context of 1970s Britain, it argues that this series was part of a burgeoning environmental discourse. First airing in February 1970 and considered "years ahead of its time," Doomwatch was popular with the public, regularly receiving over 10 million viewers. Using Stuart Hall's "encoding and decoding," the impact of the programme on the public is assessed in this paper. The BBC Audience Research Reports reveal viewers' feelings and show that the programme did strike a chord with the public and reflected concerns about contemporary environmental problems. This article thus analyses the contribution of the series to environmental awareness in Britain, and highlights the importance of considering television, and the public's response, when assessing the "greening of Britain".

Comme l'attestent la création du ministère de l'Environnement en 1970 ou la création du Green Party en 1973, les questions environnementales devinrent un enjeu majeur en Grande-Bretagne au début des années 1970. Cet article aborde la question de l'essor des inquiétudes environnementales en étudiant une série télévisée de science-fiction produite par la BBC, Doomwatch. En replaçant cette série dans le contexte plus général du début des années 1970, cet article montre pourquoi elle doit être considérée comme partie prenante de la propagation des discours écologistes. A partir de sa première diffusion, en février 1970, cette série parfois considérée comme très en avance sur son époque, rencontra un accueil très favorable du public, et il n'était pas rare qu'elle attire 10 millions de spectateurs lors de sa diffusion. En se basant sur les travaux de Stuart Hall relatifs à "l'encodage et au décodage ", cet article a pour objectif d'évaluer l'impact de cette série télévisée sur le public. Grâce aux rapports de la BBC étudiant les réactions des téléspectateurs, on constate en effet que ce programme entrait en résonance avec de réelles inquiétudes au sein de la population britannique. Cet article tente d'évaluer l'impact de ce programme et démontre plus généralement la nécessité d'étudier les programmes télévisés, et les réactions $\mathrm{du}$ public, pour une meilleure compréhension du développement des préoccupations environnementales en Grande-Bretagne.

\section{INDEX}

Keywords: environment, popular culture, television, Doomwatch, BBC, 1970s

Mots-clés: environnement, culture populaire, télévision, Doomwatch, BBC, années 1970

\section{AUTHOR}

\section{MARK WILSON}

Central University of Finance and Economics, Beijing 